\begin{tabular}{l|l|l|l|l}
\hline Volume 2 & Issue 1 & February (2022) & DOI: 10.47540/ijias.v2i1.385 & Page: $23-30$ \\
\hline
\end{tabular}

\title{
Analysis of Media Communication Systems Utilization for Natural Disaster Emergency Response Management in Reducing The Risk of Victims in Southeast Sulawesi
}

\author{
Sirajuddin ${ }^{1}$, Hafied Cangara ${ }^{2}$, Dadang A. Suriamihardja ${ }^{2}$, Andi Alimuddin Unde ${ }^{2}$ \\ ${ }^{1}$ Department of Communication Science, Universitas Halu Oleo, Indonesia \\ ${ }^{2}$ Department of Communication Science, Universitas Hasanuddin, Indonesia \\ Corresponding Author: Sirajuddin; Email: sirajuddinsept@uho.ac.id
}

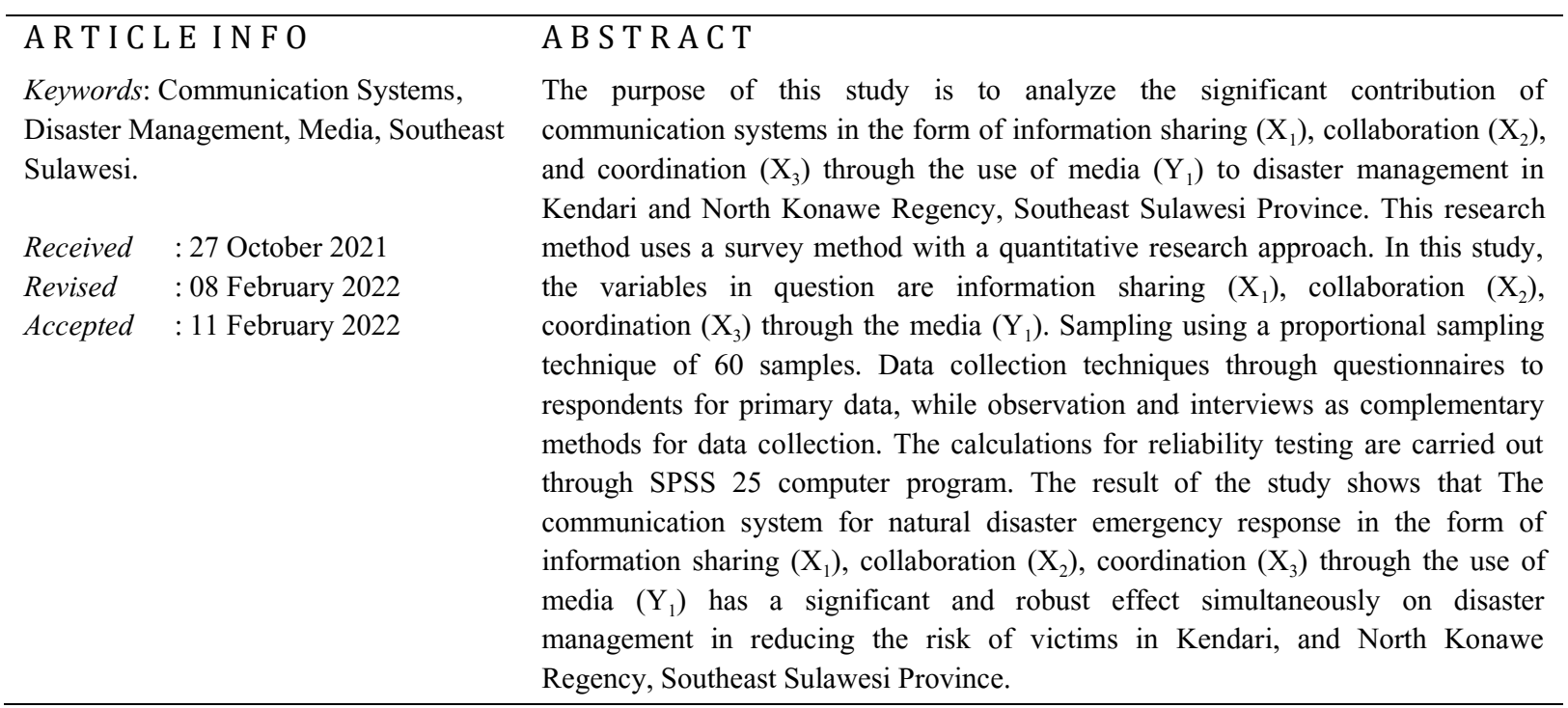

\section{INTRODUCTION}

The term disaster communication has not yet become a popular concept in communication and the field of disaster. Although research on disaster communication itself has been widely carried out, in Indonesia, studies of communication related to disasters have only been carried out after the 2004 Aceh earthquake and tsunami disaster. However, awareness of the importance of communication in disaster management has increased recently. One of the essential points of concern regarding communication in disasters is the issue of uncertainty (Haddow \& Haddow, 2013).

Communication itself arises from the need to reduce uncertainty to act effectively to protect or strengthen the total interest in individual or group interactions (Littlejohn \& Foss, 2010). Disaster preparedness requires accurate information from public and private agencies that handle disaster victims. Disaster communication is essential not only during a disaster-related emergency but also during and before a disaster. As they say, communication is the best way to mitigate, prepare for, respond to and recover from a disaster situation. The ability to convey disaster messages to the general public, government, media, and community leaders can reduce disaster risk and save lives and the impact of disasters (Haddow \& Haddow, 2013).

To mitigate disaster risk, disaster management must be bolstered by a variety of measures, both soft and hard power. The soft power method focuses on preparing communities for disasters through socialization and information dissemination. Meanwhile, hard power refers to an attempt to mitigate calamities through physical development. On the other hand, the development 
of the Internet of Things (IoT) and big data technology greatly help mitigation be more effective and accurate. This technology can realize 4.0 mitigation which is very important in reducing the risk of natural disasters.

By using big data and IoT, the flood early warning system can be better. Water flow control for flood prevention can be carried out more quickly following the measurable capacity of the disaster. Global awareness of disasters has increased since climate change emerged. A series of disasters must realize the importance of realizing a resilient mitigation system. Insufficient mitigation so far has been exacerbated by the absence of local government crisis management. The weakness of the local government's mitigation system has the effect of losing control after the disaster.

The implementer of disaster management according to the law is the National Disaster Management Agency (BNPB). This agency requires accurate data during a disaster to respond quickly, accurately in a coordinated and comprehensive manner with the relevant government agencies. It is always important to improve the mitigation system and emergency response mechanism quickly and precisely with the help of the latest technology. By providing up-to-date, accurate geospatial information, emergency response and reconstruction programs can be improved. Geospatial data platforms such as open street maps, open-source mapping projects enable rapid estimates of damage levels and monitoring of disaster management implementation.

This disaster map is based on a Geographic Information System (GIS) and is integrated with the local government e-government system. The impediment of the flow of information in the disaster area can confuse the victim's data. Then, information on the needs of refugees is not clear. Medical action was delayed, and the distribution of aid was chaotic. Natural disaster information systems must be integrated with e-government systems built by local governments and comply with the International Strategy for Disaster Reduction (ISDR) provisions. The stages are emergency response, reconstruction, rehabilitation, prevention and mitigation, and preparedness.

As the person in charge of disaster management, the regional head should also have a natural disaster decision-making support system that is very much needed to expedite the process of identifying victims, material and infrastructure losses. This system support can also be a consideration for decision-making in the rehabilitation process. The research location was chosen in Southeast Sulawesi Province, considering that this area is prone to disasters. In addition to being an area located in a subduction zone which causes a very potential for earthquakes due to the activity of tectonic plates, these plates move relative to one another, resulting in shifts and collisions that will cause a buildup of energy that has the potential to cause an earthquake.

In the Kendari City Disaster Management Emergency Plan (RKPB) document (2019) Konawe Regency Disaster Management Emergency Plan (RKPB), 2019, it is explained that the Southeast Sulawesi Province area is quite potential for seismic earthquakes, it appears that the earthquake points (epicenters) are spread along the peninsula of Southeast Sulawesi Province.

In addition, Southeast Sulawesi Province is an area that is at high risk of being affected by weather and climate-related disasters or hydrometeorological disasters. The number of disaster events in 2013-2019 caused much vital infrastructure in this region to be damaged and not a few materials and non-material losses that became a burden for all parties, both the government and the community. These various disasters are sure to disrupt the process of sustainable development planning, damage sustainable ecosystems, and the environment, and contribute to the increase in poverty and other social problems. For example, by processing data from the Indonesian Disaster Information Data (DIBI) of the National Disaster Management Agency (BNPB), the flood disaster that hit Southeast Sulawesi Province from 2009 reached 413 incidents with 118 fatalities a total of 131,920 residents had to evacuate. For damage, houses were heavily damaged, reaching 3,969 units, and 15,827 houses were slightly damaged.

In response to various events, both nationally and regionally, the government has taken various responsive and preventive actions. This condition is also confirmed by enacting Law Number 24 of 2007 concerning Disaster Management as the Legal Basis for the Implementation of Disaster Management in Indonesia. Various regulatory products in dealing with disasters have been made, but there are still 
various shortcomings in disaster management practices. One example of disaster communication management practices that have not been maximized is the earthquake disaster.

The problem in disaster management lies in coordination. So the factor of cooperation and collaboration is a crucial factor in disaster management. Prizzia (2008) explained that disaster management requires good coordination. The effectiveness of the response depends on the coordination among the departments that have responsibility for the disaster. If you look at the condition of disaster management in Indonesia, the research results can be taken into consideration that disaster management requires effective coordination.

On the other hand, the media aspect also plays an essential role in disaster management. The role of television media, in particular, is to broadcast the (same) image repeatedly for days without drawing a line of relevance to the actuality of events. Media becomes redundant and loses its essence and context.

As an information provider institution, the media has become the center of public attention, particularly the various disaster events in Indonesia. Positively the media can be the first source to inform events, show developments and psychologically encourage the public's humanity and become a mediator for disaster relief.

Disaster communication planning includes planning and availability of information through important media in disaster management (Lee, 2008). In addition to the coordination and media aspects, the cooperation aspect is also an important part of disaster management. (LaFeber \& Lind, 2008).

There are several other studies related to communication in a disaster. Such as technology and information sharing systems for natural disaster response (Bjerge, Clark, Fisker, \& Raju, 2016; Usuda, Hanashima, Sato, \& Sano, 2017; Waring et al., 2018), the content of media used to provide information to the public about disaster management (Amine \& Meguenni, 2019; Chen, Gibbs, \& Lin, 2021; Dong, Meng, Christenson, \& Fulton, 2021), network usage in disaster detection (Alfalqi \& Bellaiche, 2021; Ragini, Anand, \& Bhaskar, 2018) as well as human behavior and perception response natural disaster (Endsley, Wu,
Reep, Eep, \& Reep, 2014; Tyshchuk \& Wallace, 2018).

However, from those research, there are still few studies that emphasize several variables as system factors that have a contribution in disaster management which include aspects of information sharing, collaboration, and coordination as independent variables, then media as an intermediate variable, and victim risk reduction as the dependent variable. So it is necessary to do further research on this matter. This study aims to analyze the significant contribution of communication systems in the form of information sharing $\left(\mathrm{X}_{1}\right)$, collaboration $\left(\mathrm{X}_{2}\right)$, and coordination $\left(\mathrm{X}_{3}\right)$ through the use of media $\left(\mathrm{Y}_{1}\right)$ to disaster management in Kendari and North Konawe Regency, Southeast Sulawesi Province.

\section{METHODS}

The research was conducted in Kendari and North Konawe Regency, Southeast Sulawesi Province. This research method uses a survey method with a quantitative research approach (Apuke, 2014; Gulraiz \& Ali, 2021). In this study, the variables in question are information sharing $\left(\mathrm{X}_{1}\right)$, collaboration $\left(\mathrm{X}_{2}\right)$, coordination $\left(\mathrm{X}_{3}\right)$ through the media $\left(\mathrm{Y}_{1}\right)$. Sampling using a proportional sampling technique of 60 samples consisting of Provincial BPBD, Kendari City BPBD, North Konawe Regency BPBD, Meteorology, Climatology and Geophysics Agency (BMKG), National Search and Rescue Agency (Basarnas), Indonesian National Army (TNI), Indonesian National Police (POLRI), Indonesian Red Cross (PMI) Southeast Sulawesi, Regional Apparatus Organizations (OPD) Kendari City and North Konawe Regency, NGOs, Religious Leaders, Traditional Leaders, Community Leaders.

Data collection techniques through questionnaires to respondents for primary data, while observation and interviews as complementary methods for data collection. Questionnaires, conducted by distributing a list of questions compiled based on data indicators operationalized from the variables to be studied to the officers selected as research samples (respondents), are used to explore primary data. The questionnaire was arranged in the form of a Guttman scale. A list of questions was compiled with five answer choices in each item, with the classification of Very 
Incompatible, Incompatible, Neutral, Compatible, Very compatible.

The validity test used is product-moment correlation by correlating the answer scores on each question item with the total score-measurement of reliability in this study using the Cronbach alpha method. Instruments are said to be reliable if the reliability coefficient is at least 0.60 . The calculations for reliability testing are carried out with the help of the SPSS 25 computer program.

\section{RESULTS AND DISCUSSION}

The Effect of Information Sharing $\left(X_{1}\right)$, Collaboration $\left(X_{2}\right)$, Coordination $\left(X_{3}\right)$ through the Media $\left(Y_{1}\right)$ on Disaster Management in Kendari and The North Konawe

The effect of the communication system for responding to natural disasters in the form of information sharing $\left(\mathrm{X}_{1}\right)$, collaboration $\left(\mathrm{X}_{2}\right)$, coordination $\left(\mathrm{X}_{3}\right)$ through the media $\left(\mathrm{Y}_{1}\right)$ on disaster management in Kendari City, Southeast
Sulawesi Province can be determined using statistical analysis with the help of SPSS version 25.

The results of data analysis using SPSS version 25 show that the $F_{\text {count }}$ value is 3.14 and the $F_{\text {table }}$ value is 2.99 , thus $F_{\text {count }} 3.14$ is greater than $F_{\text {table }} 2.99$. The conclusion that can be obtained from the results of the analysis is that there is an influence of the communication system for responding to natural disasters in the form of information sharing $\left(\mathrm{X}_{1}\right)$, collaboration $\left(\mathrm{X}_{2}\right)$, coordination $\left(\mathrm{X}_{3}\right)$ through the use of media for disaster management in reducing the risk of victims in Kendari, Southeast Sulawesi Province.

To determine the magnitude of the influence of the communication system for natural disasters in the form of information sharing $\left(\mathrm{X}_{1}\right)$, collaboration $\left(\mathrm{X}_{2}\right)$, coordination $\left(\mathrm{X}_{3}\right)$ through the use of media for disaster management in reducing the risk of victims in Kendari City, Southeast Sulawesi Province, it can be seen in the R square value in Table 1 below.

Table 1. The Simultaneous Effect between $\mathrm{X}_{1}, \mathrm{X}_{2}$, and $\mathrm{X}_{3}$ through $\mathrm{Y}_{2}$

Model Summary

Change Statistics

\begin{tabular}{|r|l|l|l|r|l|l|l|r|l|}
\hline Model & $\mathrm{R}$ & Rsquare & $\begin{array}{l}\text { Adjusted R } \\
\text { Square }\end{array}$ & $\begin{array}{l}\text { Std Error of } \\
\text { the Estimate }\end{array}$ & $\begin{array}{l}\text { R Square } \\
\text { Change }\end{array}$ & $\begin{array}{l}\mathrm{F} \\
\text { Change }\end{array}$ & df1 & df2 & $\begin{array}{l}\text { Sig. F } \\
\text { Change }\end{array}$ \\
\hline 1 &, $579^{\mathrm{a}}$ &, 335 &, 229 & 13,67087 &, 335 & 3,148 & 4 & 25 &, 032 \\
\hline
\end{tabular}

a. Predictors: (Constant), Media, Collaboration, Coordination, Information Sharing

Source: SPSS version 25 data processing, 2020.

Based on Table 1, it can be concluded that there is a natural disaster emergency response communication system in the form of information sharing (X1), collaboration (X2), coordination (X3) through the use of media for disaster management in reducing the risk of victims in Kendari City, Southeast Sulawesi Province by 0.579 or $57.9 \%$ and the remainder can be calculated using the following formula:

$$
\begin{aligned}
& \mathrm{e}=1-\mathrm{R}^{2} \\
& \mathrm{e}=1-0,579 \\
& \mathrm{e}=0.421
\end{aligned}
$$

The figure of $42.1 \%$ above shows that the magnitude of other factors in the model is outside the three exogenous independent variables above. In other words, the variables of disaster management through media can be explained by using exogenous independent variables in the form of information sharing, collaboration, and coordination communication systems of $57.9 \%$. While the remaining $42.1 \%$ is caused by other variables outside this study. To determine the contribution of the influence on each variable (information sharing, collaboration, and coordination) and the use of media on disaster management in reducing the risk of victims in Kendari City, it can be seen from the Beta value or standardized coefficient, while the $t$ value is used for hypothesis testing. These figures can be seen in Table 2 of the coefficients below. 
Table 2: The Effect of Variables $\mathrm{X}_{1}, \mathrm{X}_{2}$ and $\mathrm{X}_{3}$ through $\mathrm{Y}_{1}$ on $\mathrm{Z}$

\section{Coefficients}

\begin{tabular}{|c|c|c|c|c|c|c|c|c|}
\hline \multicolumn{9}{|c|}{$95,0 \%$ Confidence Interval for B } \\
\hline Model & & Unstandardized B & $\begin{array}{l}\text { Coefficients } \\
\text { Std.Error }\end{array}$ & $\begin{array}{l}\text { Standardized } \\
\text { Coefficients } \\
\text { Beta }\end{array}$ & $\mathrm{t}$ & Sig & $\begin{array}{l}\text { Lower } \\
\text { Bound }\end{array}$ & $\begin{array}{l}\text { Upper } \\
\text { Bound }\end{array}$ \\
\hline \multirow[t]{5}{*}{1} & (Constant) & 30,35 & 18,811 & & 1,613 & ,119 & $-8,392$ & 69,092 \\
\hline & $\begin{array}{l}\text { Information } \\
\text { Sharing }\end{array}$ & ,157 & ,341 & 0,089 & 461 & 649 &,- 545 & ,860 \\
\hline & Collaboration &,- 089 & ,226 &,- 071 &,- 393 & ,698 &,- 554 & ,377 \\
\hline & Coordination & ,767 & ,219 & ,586 & 3,500 & ,002 & ,316 & 1,219 \\
\hline & Media &,- 238 & ,273 &,- 165 &,- 874 & ,391 &,- 801 & ,324 \\
\hline
\end{tabular}

a. Dependet Variable : Disaster Management

Source: SPSS version 25 data processing, 2020

The results of calculations with IBM SPSS show that the influence of information sharing variables on disaster management in reducing the risk of victims in Kendari City is $8.9 \%$, the effect of collaboration variables on disaster management in reducing victim risk in Kendari City is $7.1 \%$, the effect of coordination variables on disaster management is $7.1 \%$. Disaster management in reducing the risk of victims in Kendari City by $58.6 \%$. At the same time, the effect of the use of media on disaster management in reducing the risk of victims in Kendari City is $16.5 \%$.

Furthermore The effect of the communication system for responding to natural disasters in the form of information sharing (X1), collaboration (X2), coordination (X3) through the media (Y1) on disaster management in North Konawe Regency, Southeast Sulawesi Province.

The results of data analysis using SPSS version 25 show that the $F_{\text {count }}$ value is 19.19 and the
$\mathrm{F}_{\text {table }}$ value is 2.99 , thus $\mathrm{F}_{\text {count }} 19.19$ is greater than $F_{\text {table }} 2.99$. The conclusion that can be obtained from the results of the analysis is that there is an influence of the communication system for natural disaster emergency response in the form of information sharing $\left(\mathrm{X}_{1}\right)$, collaboration $\left(\mathrm{X}_{2}\right)$, coordination $\left(\mathrm{X}_{3}\right)$ through the use of media for disaster management in reducing the risk of victims in North Konawe Regency, Southeast Sulawesi Province.

To determine the magnitude of the influence of the communication system for natural disaster emergency response in the form of information sharing $\left(\mathrm{X}_{1}\right)$, collaboration $\left(\mathrm{X}_{2}\right)$, coordination $\left(\mathrm{X}_{3}\right)$ through the use of media for disaster management in reducing the risk of victims in North Konawe Regency, Southeast Sulawesi Province, it can be seen in the value of $\mathrm{R}$ square in Table 3 below.

Table 3 Simultaneous Effect between $\mathrm{X}_{1}, \mathrm{X}_{2}$, and $\mathrm{X}_{3}$ through $\mathrm{Y}_{1}$.

Model Summary

Change Statistics

\begin{tabular}{|r|l|l|l|r|l|r|r|r|l|}
\hline Model & $\mathrm{R}$ & Rsquare & $\begin{array}{l}\text { Adjusted } \\
\text { R Square }\end{array}$ & $\begin{array}{l}\text { Std Error of } \\
\text { the Estimate }\end{array}$ & $\begin{array}{l}\text { R Square } \\
\text { Change }\end{array}$ & F Change & df1 & df2 & $\begin{array}{l}\text { Sig. F } \\
\text { Change }\end{array}$ \\
\hline 1 &, $869^{\mathrm{a}}$ &, 754 &, 715 & 8,43031 &, 754 & 19,195 & 4 & 25 &, 000 \\
\hline
\end{tabular}

a. Predictors: (Constant), Media, Information Sharing, Coordination, Collaboration

Source: SPSS version 25 data processing, 2020

Based on Table 3, it can be concluded that there is a natural disaster emergency response communication system in the form of information sharing $\left(\mathrm{X}_{1}\right)$, collaboration $\left(\mathrm{X}_{2}\right)$, coordination $\left(\mathrm{X}_{3}\right)$ through the use of media for disaster management in reducing the risk of victims in North Konawe
Regency, Southeast Sulawesi Province by 0.869 or $86.9 \%$ and the remainder can be calculated using the following formula:

$$
\begin{aligned}
& \mathrm{e}=1-\mathrm{R}^{2} \\
& \mathrm{e}=1-0,869 \\
& \mathrm{e}=0.131
\end{aligned}
$$


The variables of disaster management through media can be explained by using exogenous independent variables in the form of information sharing, collaboration, and coordination communication systems of $86.9 \%$. While other variables outside of this study cause the remaining $13.3 \%$. To determine the contribution of influence on each variable (information sharing, collaboration, and coordination) and the use of media on disaster management in reducing the risk of victims in North Konawe Regency, it can be seen from the Beta value or standardized coefficient, while the $t$ value is used for hypothesis testing. These figures can be seen in Table 4 of the coefficients below.

Table 4. The Effect of Variables $\mathrm{X}_{1}, \mathrm{X}_{2}$, and $\mathrm{X}_{3}$ through $\mathrm{Y}_{1}$ on $\mathrm{Z}$

Coefficients $^{\mathrm{a}}$

\begin{tabular}{|c|c|c|c|c|c|c|}
\hline Model & & Unstandardized B & $\begin{array}{l}\text { Coefficients } \\
\text { Std.Error }\end{array}$ & $\begin{array}{l}\text { Standardized } \\
\text { Coefficients Beta }\end{array}$ & $\mathrm{t}$ & Sig \\
\hline \multirow[t]{5}{*}{1} & (Constant) & 1,447 & 8,589 & & , 168 & ,868 \\
\hline & $\begin{array}{l}\text { Information } \\
\text { Sharing }\end{array}$ & ,339 & ,276 & 154 & , 1,227 & ,231 \\
\hline & Collaboration &,- 399 & ,232 &,- 319 & $\begin{array}{l}- \\
, 1,720\end{array}$ & ,098 \\
\hline & Coordination & $, 1,089$ & ,184 & 984 & 5,930 &, 000 \\
\hline & Media & , 199 & , 160 &,- 151 & 1,244 & ,225 \\
\hline
\end{tabular}

a. Dependet Variable : Disaster Management

Source: SPSS version 25 data processing, 2020

The results of calculations with IBM SPSS show that the influence of information sharing variables on disaster management in reducing the risk of victims in North Konawe Regency is $15.4 \%$, the effect of collaboration variables on disaster management in reducing the risk of victims in North Konawe Regency is $31.9 \%$, the influence of variables on disaster management is $31.9 \%$. Coordination of disaster management in reducing the risk of victims in North Konawe Regency by $98.4 \%$. At the same time, the effect of media on disaster management in reducing the risk of victims in the North Konawe Regency is $15.1 \%$.

\section{Information sharing variable $\left(X_{1}\right)$}

The results showed that of the 12 items of questions regarding the information sharing variable, the respondents thought that the data related to the disasters in Kendari City were not in accordance with the disaster conditions that often occurred. From the search results for national disaster data from the Meteorology and Geophysics Agency (BMKG), disaster data released in real-time is only limited to earthquake and weather data. Conceptually, the government's role in disaster management is very well planned, but in the implementation phase, there are many obstacles. Especially in disseminating disaster information, miscommunication and misinformation often occur. One example of collecting accurate disaster data and information is using the Car Navigation disaster 'car navigation system' to detect environmental conditions which then the data is sent in real-time. (Hada, Suzuki, Shimora, Meguro, \& Kodama, 2011).

\section{Collaboration variable $\left(\mathrm{X}_{2}\right)$}

In implementing disaster management, BNPB is the leading sector that can collaborate with other institutions under Law Number 24 of 2007 concerning Disaster Management. As explained earlier that collaboration with cooperation has a different concept. In disaster management, BNPB seems to only cooperate with other parties, thus triggering sectoral egos. Each institution that participates in disaster management carries out its respective main tasks and functions, both from funding, policies, operational mechanisms in the field. This condition causes frequent miscommunication between one institution and another. From the study results, it was found that each institution that is an element that participates in disaster management has its structure. Under these conditions, there will be obstacles in communication lines between organizations involved in disaster management and between 
organizations and the community. The ideal crisis response involves smooth collaboration between relevant actors, but friction between levels of government and civil society in responding to disasters is also common (Aldrich, 2019). Fakhruddin (2007) stated that communication channels both horizontally and vertically are essential in crisis communication. Disaster management requires links or connections between organizations involved in disaster management.

\section{Coordination variable $\left(\mathbf{X}_{3}\right)$}

The study results indicate that the availability of standard operating procedures for disaster management has been stipulated in the Regulation of the Head of BNPB Number 02 of 2017 concerning Guidelines for Preparing Standard Operating Procedures in the BNPB Environment. In every disaster management, coordination meetings and periodic meetings are held first. Although coordination meetings have been held between agencies/institutions involved in disaster management, miscommunication often occurs in the field, and tensions occur between institutions. This condition indicates weak coordination in the implementation of disaster management. coordination is one element in the system that provides supervision overall disaster management functions, coordination and control are impossible without communication. To achieve coordination and control, three factors need to be considered: (1) mandate; (2) power and authority; and (3) available resources (Apuke, 2014). Therefore, coordination is a crucial factor to improve the disaster emergency.

\section{Media Variable $\left(\mathbf{Y}_{1}\right)$}

The results showed that the Regional Disaster Management Agency (BPBD) collaborated with the media to provide disaster information in Kendari City and North Konawe Regency. These two areas provide information that cooperation with the media is solid. There are some print media in Southeast Sulawesi Province, such as Kendari Pos and Rakyat Sultra. Apart from print media, several online media include sultrakini.com, penaaktual.com, mysultra. com, radarsultra.com, tegas.com, portalsultra.com, mediakendari.com, koransultra.com, antarasultra. com. liputan6.com, Kompas.com, and several other online media.

Media are the most significant mitigation tool for manager officials because its content creates disaster and risk awareness. There are three actors in an effective disaster management process: government officials who present disaster information, the media that disseminate it, and the public, who receive information and act on it (Perez-Lugo, 2001).

\section{ConCLUSION}

The communication system for natural disaster emergency response in the form of information sharing $\left(\mathrm{X}_{1}\right)$, collaboration $\left(\mathrm{X}_{2}\right)$, coordination $\left(\mathrm{X}_{3}\right)$ through the use of media $\left(\mathrm{Y}_{1}\right)$ has a significant and robust effect simultaneously on disaster management in reducing the risk of victims in North Konawe Regency, Southeast Sulawesi Province. Variables of disaster management through media can be explained by using exogenous independent variables in the form of communication systems in the form of information sharing, collaboration, and coordination. If tested separately (partial), then the coordination variable has a strong and significant effect on disaster management in reducing the risk of victims in the North Konawe Regency. This condition is almost the same as the communication system for natural disaster emergency response in the form of information sharing $\left(\mathrm{X}_{1}\right)$, collaboration $\left(\mathrm{X}_{2}\right)$, coordination $\left(\mathrm{X}_{3}\right)$ through the use of media, which has a strong and significant effect simultaneously on disaster management in reducing the risk of victims in Kendari City, Southeast Sulawesi Province. If tested separately (partial), then the coordination variable for disaster management in reducing the risk of victims in Kendari City.

\section{REFERENCES}

1. Aldrich, D. P. (2019). Challenges to Coordination: Understanding Intergovernmental Friction During Disasters. International Journal of Disaster Risk Science, 10(3), 306-316.

2. Alfalqi, K., \& Bellaiche, M. (2021). IoT-Based Disaster Detection Model Using Social Networks and Machine Learning. 2021 4th International Conference on Artificial Intelligence and Big Data (ICAIBD), 92-97.

3. Amine, H. M., \& Meguenni, B. (2019). A Web Platform for Crisis Management Based on Voluntary Data and Free Tools in Case of Natural Disaster. The International Archives of the Photogrammetry, Remote Sensing and 
Spatial Information Sciences, XLII-3/W8, 127131.

4. Apuke, O. D. (2014). Coordination and control. Scandinavian Journal of Public Health, 42(14_suppl), 56-75.

5. Bjerge, B., Clark, N., Fisker, P., \& Raju, E. (2016). Technology and Information Sharing in Disaster Relief. PLOS ONE, 11(9), e0161783. https://doi.org/10.1371/journal.pone.0161783

6. Chen, I., Gibbs, J. L., \& Lin, J. (2021). Understanding and Designing for Disaster Preparation on Social Media. Extended Abstracts of the 2021 CHI Conference on Human Factors in Computing Systems, 1-6. New York, NY, USA: ACM.

7. Dong, Z. S., Meng, L., Christenson, L., \& Fulton, L. (2021). Social media information sharing for natural disaster response. Natural Hazards, 107(3), 2077-2104.

8. Endsley, T., Wu, Y., Reep, J., Eep, J., \& Reep, J. (2014). The source of the story: Evaluating the credibility of crisis information sources. ISCRAM.

9. Fakhruddin, S. H. M. (2007). Emergency communications for disaster management. Asian Disaster Preparedness Center, 13(1), 125.

10. Gulraiz, K., \& Ali, A. (2021). Expressed Willingness and Awareness of Students towards Climate Change in Lahore, Pakistan. Indonesian Journal of Innovation and Applied Sciences (IJIAS), 1(3), 219-228.

11. Hada, Y., Suzuki, T., Shimora, H., Meguro, K., \& Kodama, N. (2011). Issues and future prospect on practical use of probe vehicle data for disaster reduction-provision of the vehicle tracking map in the 2007 niigataken chuetsuoki earthquake. Journal of Japan Association for Earthquake Engineering, 9(2), 2_1482_159.

12. Haddow, G., \& Haddow, K. (2013). Disaster communications in a changing media world. Butterworth-Heinemann.

13. LaFeber, P., \& Lind, N. S. (2008). Disaster management and intergovernmental relations. In Disaster management handbook (pp. 583590). CRC Press.

14. Lee, M. (2008). Media relations and external communications during a disaster. In Disaster management handbook (pp. 417-430). CRC
Press.

15. Littlejohn, S. W., \& Foss, K. A. (2010). Theories of human communication. Waveland press.

16. Perez-Lugo, M. (2001). The Mass Media and Disaster Awareness in Puerto Rico. Organization \& Environment, 14(1), 55-73.

17. Prizzia, R. (2008). The role of coordination in disaster management. Taylor and Francis.

18. Ragini, J. R., Anand, P. M. R., \& Bhaskar, V. (2018). Big data analytics for disaster response and recovery through sentiment analysis. International Journal of Information Management, 42, 13-24.

19. Tyshchuk, Y., \& Wallace, W. A. (2018). Modeling Human Behavior on Social Media in Response to Significant Events. IEEE Transactions on Computational Social Systems, 5(2), 444-457.

20. Usuda, Y., Hanashima, M., Sato, R., \& Sano, H. (2017). Effects and Issues of Information Sharing System for Disaster Response. Journal of Disaster Research, 12(5), 1002-1014.

21. Waring, S., Alison, L., Carter, G., Barrett-Pink, C., Humann, M., Swan, L., \& Zilinsky, T. (2018). Information sharing in interteam responses to disaster. Journal of Occupational and Organizational Psychology, 91(3), 591619. 